PAPER

\title{
Chronic deep brain stimulation for the treatment of tremor in multiple sclerosis: review and case reports
}

\author{
H A Wishart, D W Roberts, R M Roth, B C McDonald, D J Coffey, A C Mamourian, C Hartley, \\ L A Flashman, C E Fadul, A J Saykin
}

J Neurol Neurosurg Psychiatry 2003;74:1392-1397

See end of article for authors' affiliations avth' affiliations

Correspondence to: Dr H A Wishart, Department of Psychiatry, Dartmouth Medical School, DartmouthHitchcock Medical Center, Lebanon, New Hampshire 03756-0001, USA; heather.wishart@ dartmouth.edu
M ultiple sclerosis can be associated with tremor in the arms, legs, trunk, and head, although the upper extremities are most commonly affected..$^{12}$ In a recent study of 100 outpatients with definite multiple sclerosis, action tremor was detected on neurological examination in 58 cases, while in contrast to some previous reports, rest and rubral tremors were not observed. ${ }^{1}$ The action tremor of multiple sclerosis can have postural or kinetic components (including intention), and may affect the more proximal or more distal forearm. ${ }^{1-3}$ In general, tremor associated with multiple sclerosis is thought to be related to dysfunction of the cerebellum or its connections, though further research is needed to explore its pathophysiology fully. ${ }^{1}$

Medical treatment of tremor in multiple sclerosis is often less than satisfactory ${ }^{12}$ and ablative thalamotomy, while effective in selected patients, ${ }^{4}$ may not produce sustained benefit. ${ }^{5}{ }^{6}$ Chronic deep brain stimulation (DBS) through implanted electrodes provides an alternative. Given the success of DBS in the treatment of Parkinson's disease and essential tremor, this procedure has also been used in multiple sclerosis. In this paper we present a review of the published reports on this subject, as well as a case series of individuals who received bilateral implantation at our centre.

\section{METHODS}

Papers for the literature review were located using relevant keywords (deep brain stimulation, neurostimulation, thalamic stimulation, multiple sclerosis) and associated search terms in Ovid Medline 1966 to 2002, and by searching the reference list of each article recovered. This strategy yielded 14 full reports of DBS in multiple sclerosis, all of which contained data relevant to the review (table 1). All studies were modest in size, ranging from one to 14 patients. Across all studies, the total number of patients who received completed DBS implantation was 75; in some cases, additional patients were initially studied, but DBS implantation was not completed for various reasons (see Results). In some studies, the patients with multiple sclerosis were part of a larger sample composed mainly of individuals with Parkinson's disease or essential tremor. Follow up periods ranged from less than three months to more than 12 months, with most studies $(\mathrm{n}=7)$ in the 6 to 12 month range. Each study was reviewed for selection criteria, surgical target, and primary outcome variables, including tremor suppression, improvement in daily functioning, and adverse effects.

For the purpose of this review, tremor suppression was defined according to the percentage of patients showing sustained improvement (to the end of the study period), to any degree and on any type of tremor scale or tremor measurement device. Improvement in daily functioning was defined according to the percentage of patients showing sustained improvement in functions such as feeding, holding and manipulating household objects, and quality of life. For the most part, reports of improvement in daily functioning were based on patient self report, while improvement in tremor control was based on paper and pencil testing, tremor amplitude scales, or tremor measurement devices. Also included in this report are original data from the complete consecutive series $(n=4)$ of multiple sclerosis patients who have received DBS implantation at our hospital.

\section{RESULTS}

Review of previously published data Inclusion criteria and sample characteristics Six studies reported explicit criteria for selecting patients for DBS surgery (Montgomery et al, ${ }^{3}$ Hooper et al, ${ }^{17}$ Benabid et al, ${ }^{10}$ 
Table 1 Studies describing chronic deep brain stimulation in multiple sclerosis

\begin{tabular}{|c|c|c|c|c|c|c|c|}
\hline Study [ref] & $n^{*}$ & $\begin{array}{l}\text { Inclusion criteria/ } \\
\text { sample characteristics }\end{array}$ & Locus & Follow up & Adverse effects & $\begin{array}{l}\text { Tremor } \\
\text { suppressiont }\end{array}$ & $\begin{array}{l}\text { Effect on daily } \\
\text { functionsł }\end{array}$ \\
\hline $\begin{array}{l}\text { Brice and } \\
\text { McLellan, } 1980^{7}\end{array}$ & 2 & $\begin{array}{l}\text { Severe disabling tremor; } \\
\text { sensation, power, finger } \\
\text { movements relatively } \\
\text { well preserved; clinically stable } \\
\text { for } 6 \text { months; } \\
\text { failure to respond to } \\
\text { drug treatment }\end{array}$ & $\begin{array}{l}\text { Bilateral } \\
\text { subthalamic }\end{array}$ & $5-6$ months & Not reported separately & $100 \%$ & $100 \%$ \\
\hline $\begin{array}{l}\text { Nguyen and } \\
\text { Degos, } 1993^{8}\end{array}$ & 1 & Severe tremor & $\begin{array}{l}\text { Unilateral } \\
\text { VIM }\end{array}$ & 17 months & None reported & $100 \%$ & $100 \%$ \\
\hline $\begin{array}{l}\text { Seigfried and } \\
\text { Lippitz, } 1994^{9} \S\end{array}$ & 9 & Not reported & $\begin{array}{l}\text { Unilateral } \\
\text { VIM }\end{array}$ & Not reported & None & $78 \%$ & Not reported \\
\hline $\begin{array}{l}\text { Benabid et al, } \\
1996^{10}\end{array}$ & 4 & $\begin{array}{l}\text { Severe tremor; failure to } \\
\text { respond to drug treatment }\end{array}$ & VIM & $\begin{array}{l}3 \text { to } \geqslant 6 \\
\text { months }\end{array}$ & $\begin{array}{l}\text { Microhaematoma (1 MS } \\
\text { patient); no other persistent } \\
\text { effects; transitory effects not } \\
\text { separately reported for MS } \\
\text { subsample }\end{array}$ & $50 \%$ & $\begin{array}{l}\text { Not reported } \\
\text { separately }\end{array}$ \\
\hline $\begin{array}{l}\text { Geny et al, } \\
1996^{11}\end{array}$ & 13 & $\begin{array}{l}\text { Disabling tremor; no } \\
\text { relapse within preceding } \\
6 \text { months }\end{array}$ & $\begin{array}{l}\text { Unilateral } \\
\text { VIM }\end{array}$ & 3 months & $\begin{array}{l}\text { Transitory paresis in lower } \\
\text { limb (1 case); dysaesthesiae } \\
\text { of }<1 \mathrm{~min} \text { at onset of } \\
\text { stimulation (all cases); } \\
\text { asthenia ( } 1 \text { case) }\end{array}$ & $69 \%$ & $92 \%$ \\
\hline $\begin{array}{l}\text { Whittle et al, } \\
1998^{12}\end{array}$ & 5 & $\begin{array}{l}\text { Disabling UE movement } \\
\text { disorder; absence of } \\
\text { predominantly postural } \\
\text { axial tremor or severe } \\
\text { neurological dysfunction; } \\
\text { ability to locate an } \\
\text { effective surgical target }\end{array}$ & $\begin{array}{l}\text { Ventrolateral } \\
\text { thalamus }\end{array}$ & Not reported & Mood disturbances in some & $\begin{array}{l}\text { Benefit in some } \\
\text { or all patients; } \\
\text { no detailed report }\end{array}$ & Not reported \\
\hline Hay, $1999^{13}$ & 1 & $\begin{array}{l}\text { Not specifically reported } \\
\text { (single case study) }\end{array}$ & $\begin{array}{l}\text { Unilateral } \\
\text { thalamus }\end{array}$ & 2 months & None reported & $100 \%$ & Not reported \\
\hline $\begin{array}{l}\text { Montgomery et al, } \\
1999^{3}\end{array}$ & 14 & $\begin{array}{l}\text { Disabling UE tremor } \\
\text { without other weakness, } \\
\text { sensory, or other } \\
\text { problems that would } \\
\text { continue to limit } \\
\text { functioning; clinically } \\
\text { stable for } 6 \text { months; } \\
\text { no significant speech } \\
\text { or swallowing problems; } \\
\text { no severe cognitive } \\
\text { disability }\end{array}$ & VIM & $<3-12+$ month & $\begin{array}{l}\text { Is Intracerebral haematoma } \\
\text { (1 case); transient } \\
\text { paraesthesiae when } \\
\text { stimulator turned on } \\
\text { (most cases) }\end{array}$ & $100 \%$ & Not reported \\
\hline $\begin{array}{l}\text { Schulder et al, } \\
1999^{2}\end{array}$ & 5 & $\begin{array}{l}\text { Disabling UE tremor; } \\
\text { failure to respond to } \\
\text { drug treatment }\end{array}$ & $\begin{array}{l}\text { Unilateral } \\
\text { VIM }\end{array}$ & $\geqslant 6$ months & None & $100 \%$ & $60 \%$ \\
\hline $\begin{array}{l}\text { Taha et al, } \\
1999^{14 * *}\end{array}$ & 2 & $\begin{array}{l}\text { Bilateral limb tremor, } \\
\text { head tremor, or voice } \\
\text { tremor }\end{array}$ & VIM & $\sim 10$ months & $\begin{array}{l}\text { Not reported separately } \\
\text { for MS patients; no } \\
\text { haemorrhage or infarction }\end{array}$ & $100 \%$ & Not reported \\
\hline $\begin{array}{l}\text { Schuurman et al, } \\
2000^{15}\end{array}$ & 5 & $\begin{array}{l}\text { Severe UE tremor present } \\
\text { at least one year despite } \\
\text { drug treatment; age } 18 \\
\text { or older; no significant } \\
\text { cognitive dysfunction; } \\
\text { no contraindications to } \\
\text { surgery; no advanced } \\
\text { cerebral atrophy; no } \\
\text { previous thalamotomy }\end{array}$ & $\begin{array}{l}\text { Unilateral } \\
\text { or Bilateral } \\
\text { VIM }\end{array}$ & 6 months & $\begin{array}{l}\text { Dysarthria, gait/balance } \\
\text { disturbance, arm ataxia } \\
\text { (3 patients); intracerebral } \\
\text { haemorrhage ( } 1 \text { case of } \\
\text { entire larger sample) }\end{array}$ & $\begin{array}{l}\text { General } \\
\text { improvement, } \\
\text { not individually } \\
\text { reported }\end{array}$ & $\begin{array}{l}\text { No significant } \\
\text { overall } \\
\text { improvement; } \\
\text { not } \\
\text { individually } \\
\text { reported }\end{array}$ \\
\hline $\begin{array}{l}\text { Matsumoto et al, } \\
2001^{16}\end{array}$ & 3 & $\begin{array}{l}\text { Severe UE tremor; } \\
\text { clinically definite MS; } \\
\text { no significant weakness } \\
\text { or sensory loss in the } \\
\text { hands; absence of arrhythmic } \\
\text { movement disorder; clinically } \\
\text { stable } \\
\text { for preceding } 3 \text { months; } \\
\text { no dementia }\end{array}$ & $\begin{array}{l}\text { Unilateral } \\
\text { VIM }\end{array}$ & 12 months & None & $100 \%$ & $0 \%$ \\
\hline $\begin{array}{l}\text { Hooper et al, } \\
2002^{17^{5}}+\dagger\end{array}$ & 10 & $\begin{array}{l}\text { Disabling UE tremor for at } \\
\text { least } 12 \text { months that had } \\
\text { not responded to drug } \\
\text { treatment; established } \\
\text { diagnosis of } M S \text {; no major } \\
\text { relapse for } 6 \text { months; no } \\
\text { severe sensory or motor } \\
\text { impairment that would } \\
\text { continue to limit functioning; } \\
\text { capacity to give informed } \\
\text { consent }\end{array}$ & $\begin{array}{l}\text { Unilateral } \\
\text { thalamus }\end{array}$ & 12 months & $\begin{array}{l}\text { Upper limb paraesthesiae } \\
\text { when the DBS was turned } \\
\text { on; transitory limb } \\
\text { weakness ( } 2 \text { cases), } \\
\text { infection at site of IPG } \\
\text { necessitating its removal } \\
\text { (1 case); intraoperative } \\
\text { hypoxic episode (1 case); } \\
\text { small thalamocapsular } \\
\text { haemorrhages at site of DBS } \\
\text { implantation with persistent } \\
\text { changes in functioning } \\
\text { ( } 2 \text { cases); seizures ( } 2 \text { cases, } \\
1 \text { seizure each) }\end{array}$ & $100 \%$ & $\begin{array}{l}68 \text { to } 78 \% \\
\text { were same or } \\
\text { better } \\
\text { at } 12 \text { months } \\
\text { on } \\
\text { two scales; } \\
\text { other } \\
\text { measures } \\
\text { showed } \\
\text { no effect }\end{array}$ \\
\hline
\end{tabular}


Table 1 Continued

\begin{tabular}{|c|c|c|c|c|c|c|c|}
\hline Study [ref] & $n^{*}$ & $\begin{array}{l}\text { Inclusion criteria/ } \\
\text { sample characteristics }\end{array}$ & Locus & Follow up & Adverse effects & $\begin{array}{l}\text { Tremor } \\
\text { suppression† }\end{array}$ & $\begin{array}{l}\text { Effect on daily } \\
\text { functions } \ddagger\end{array}$ \\
\hline $\begin{array}{l}\text { Nandi et al, } \\
2002^{18}\end{array}$ & 1 & $\begin{array}{l}\text { Severe, disabling, } \\
\text { progressively worsening } \\
\text { UE tremor; gait } \\
\text { dysfunction with leg ataxia } \\
\text { (single case study) }\end{array}$ & $\begin{array}{l}\text { Unilateral } \\
\text { zona incerta }\end{array}$ & 12 months & $\begin{array}{l}\text { Worsening of walking and } \\
\text { left foot dystonia developed } \\
\text { between approximately } \\
\text { months } 9 \text { and } 12\end{array}$ & $100 \%$ & $100 \%$ \\
\hline
\end{tabular}

*Number of patients with multiple sclerosis in whom implantation of a chronic stimulator was completed.

†As measured by the percentage of patients showing any sustained improvement (to the end of the follow up period in study) to any degree on any type of tremor scale or instrumentation.

$\ddagger$ As measured by the percentage of patients showing sustained improvement in daily functions such as feeding, holding and manipulating household objects, or subjective quality of life in everyday contexts.

§One patient with multiple sclerosis had bilateral stimulators; data available are for unilateral stimulation (first side).

-Additional clinical follow up data available. Tremor suppression data are for proximal upper extremity tremor; additional less consistent improvement occurred in distal upper extremity and some improvement occurred in those with lower extremity tremor.

** Mean follow up period was 10 months for the entire sample, including six patients with Parkinson's disease, 15 with essential tremor, and two with multiple sclerosis; the follow up period for the two patients with multiple sclerosis was not reported separately. In the entire sample, 19 patients underwent either staged or simultaneous VIM implantation, while four received thalamotomy followed by unilateral VIM implantation; it is unclear whether either of the patients with multiple sclerosis was among the minority receiving the combination of thalamotomy and DBS.

t†Specific targets within the thalamus were $1 \mathrm{~mm}$ posterior to AC-PC midpoint and from 11-15 mm lateral to midline, adjusted in $2 \mathrm{~mm}$ increments to the locus where stimulation produced tremor suppression without adverse neurophysiological effects.

MS, multiple sclerosis; UE, upper extremity; VIM, ventrointeromedial nucleus of the thalamus.

Whittle et al, ${ }^{12}$ Schurrman et al,,$^{15}$ Matsumoto et al, ${ }^{16}$ ), while the others generally provided sample or case descriptions (table 1). Inclusion criteria or sample characteristics included severe or disabling tremor in 11 of the 14 studies. Other relatively common factors were failure to respond to medical treatment (five studies), absence of other severe sensory or motor problems that would continue to limit functioning even if tremor were alleviated (five studies), clinically stable disease for three to six months before surgery (five studies), and relatively preserved cognitive function (four studies). Additional specific factors are listed in table 1. Other investigators may have used these or other inclusion/ exclusion criteria, but did not describe them in their reports. Most studies did not specify the numbers of patients who were considered but rejected for surgery, possibly because selection had begun earlier in the referral process, before the study authors had contact with the patients. An exception is the study by Whittle et $a{ }^{12}$ in which it was reported that 12 of 17 patients referred for surgery did not complete the procedure because they did not meet inclusion criteria (table 1). Another is the study by Matsumoto et $a l^{16}$ in which seven of 16 patients referred for surgery did not have the procedure, including two who met inclusion criteria but declined the surgery, four who were denied insurance coverage, and one whose movement disorder was ultimately deemed to be ataxia. Of note, the remaining patients in the Matsumoto study received either thalamotomy $(n=6)$ or DBS $(n=3)$ but the results were reported for the most part considering both groups together.

\section{Surgical procedures}

The surgical target for DBS implantation was the ventrointeromedial nucleus of the thalamus (VIM) in the majority of studies (table 1). Alusi et al noted that the nucleus ventralis oralis posterior rather than the VIM has also been chosen by some as a preferred target for DBS implantation in multiple sclerosis. ${ }^{4}$ Most groups reported detailed intraoperative stimulation and recording procedures for refining the ultimate location of implantation, based on maximising tremor suppression while minimising adverse effects. Geny and colleagues observed that the effective VIM site in multiple sclerosis is often dorsal and lateral to the VIM site that is effective in Parkinson's disease, and that the exact location of the stimulator within the VIM must be selected with attention to the somatotopic distribution within the nucleus. ${ }^{11}$ Nguyen and Degos found that stimulation of the upper VIM region was most effective in controlling proximal tremor, while stimulation of the lower part of the VIM was most effective in controlling distal tremor. ${ }^{8}$ In most cases, stimulator implantation was unilateral, but bilateral implantations (either staged or simultaneous) and implantations contralateral to a previous thalamotomy were also reported. In a small number of studies, chronic implantation of DBS was intended but not completed at the time of surgery. Reasons for failure to proceed to implantation included complications during surgery (one of 15 cases in the Montgomery series ${ }^{3}$ ); failure to locate an effective target (three of eight patients who otherwise met inclusion criteria in the Whittle series ${ }^{12}$; three of 15 cases in the Hooper series $\left.^{5}\right)$; and a positive benefit of microelectrode insertion alone (two of 15 cases in the Hooper series ${ }^{17}$ ).

\section{Tremor suppression and daily functioning}

Tremor reduction and improvement in daily functioning were achieved in the majority of cases (table 1). Twelve of the 14 studies reported sufficient data to determine the percentage of patients experiencing improved tremor control. Those 12 studies involved a total of 65 patients, of whom 57 (88\%) experienced sustained improvement in tremor control postsurgery. Effects on daily functioning were less consistently assessed across studies, with only six studies reporting sufficient data to determine effects in this domain. These six studies involved 25 patients, of whom 19 (76\%) experienced improvement in daily functioning. Although data on frequency of reprogramming were not generally reported in detail in these studies, it appeared that reprogramming was required relatively often to maintain optimal tremor control while minimising undesired side effects.

\section{Adverse effects}

Across all 14 studies, intracerebral haemorrhage occurred in four or possibly five patients. ${ }^{3} 1015$ One was a microhaematoma, the effects of which resolved within three months. ${ }^{10}$ In the case of Montgomery et al, ${ }^{3}$ the haematoma was attributable to the surgery rather than to the stimulator (which was never placed), and the patient also experienced tremor reduction and transient dysarthria. Two cases involved small thalamocapsular haemorrhages at the site of DBS implantation which led to persistent changes in functioning. ${ }^{17}$ In another study, which included patients with various tremor aetiologies, there was relatively little 
detail about the haemorrhage and it was unclear whether or not it was a patient with multiple sclerosis who was affected. ${ }^{15}$

In the entire sample of 75 patients in whom DBS implantation was completed, one developed a recurrent infection at the site of the internal pulse generator, which necessitated removal of the unit ${ }^{17}$; and two had seizures, one at one week postsurgery and the other at eight weeks. ${ }^{17}$ Paraesthesiae at the onset of stimulation were relatively common across studies, but tended to be brief and mild. Other adverse effects were generally mild and in some cases transitory, and included dysarthria, disequilibrium, and limb weakness.

Six studies reported data on the presence or absence of exacerbations of multiple sclerosis after surgery (table 2). These studies involved 38 patients, of whom six or seven (16-18\%) had an exacerbation within the follow up period. Only three of those exacerbations occurred within a month of surgery. Given variable presurgical baselines and postoperative follow up periods across studies, it was unclear whether this represented a significant change from the patients' baseline status. Only three studies (involving 18 patients) reported sufficient data to allow calculation of annualised per patient exacerbation rates before and after surgery. ${ }^{7116}$ All three of these studies gave a baseline exacerbation rate of zero (because recent exacerbation was an exclusion factor for surgery). Postoperatively, the annualised exacerbation rate was 0.17 per patient in these three studies.

\section{Dartmouth-Hitchcock case series}

Table 3 presents the data for the small consecutive series of patients with multiple sclerosis who have received DBS surgery for treatment of drug refractory tremor at our medical centre. This sample is distinct in that all patients had bilateral stimulator implantation (either staged or simultaneous). In addition, the follow up period from initial surgery averaged approximately 22 months, somewhat longer than many of the reports published to date. The surgical target was the ventrolateral thalamus in all cases, with the ultimate placement being determined on the basis of intraoperative response. One additional patient had a seizure intraoperatively, so implantation was not completed; that patient remains a potential candidate for surgery at a future date. The four remaining patients all experienced a significant improvement in tremor control postsurgery, and in each case better tremor control translated into improvements in aspects of daily functioning. However, reprogramming was needed to maintain optimal tremor control, and even so, the degree of control was not necessarily equal for left and right extremities. In addition, tremor control on at least one side clearly declined over time in three cases, though all patients still functioned above their presurgical baselines. One patient reported the sudden onset of unpleasant

Table 2 Exacerbations of multiple sclerosis before and after surgery

\begin{tabular}{|c|c|c|c|c|}
\hline Study [ref] & $\mathbf{n}$ & $\begin{array}{l}\text { Exacerbation-free } \\
\text { baseline (months) }\end{array}$ & $\begin{array}{l}\text { Follow up period for } \\
\text { exacerbation data } \\
\text { (months) }\end{array}$ & $\begin{array}{l}\text { Postoperative } \\
\text { exacerbations }\end{array}$ \\
\hline $\begin{array}{l}\text { Brice and } \\
\text { McLellan, } \\
1980^{7}\end{array}$ & 2 & 6 months & 5-6 months & 0 \\
\hline $\begin{array}{l}\text { Geny et al, } \\
1996^{11}\end{array}$ & 13 & 6 months & 12 months & 3 \\
\hline
\end{tabular}

Comments

No changes in clinical status consistent with relapse occurred

Three patients had a relapse of their MS at 4, 6, and 12 months postsurgery, respectively; no change in average EDSS for the group Montgomery 146 months $<3-12+$ months et ${\text { al, } 1999^{3}}^{3}$

6 1 One patient had an exacerbation 3 days postsurgery, at the time of a UTI. This decreased the patient's lower extremity power and necessitated increased use of a wheelchair Two patients had an exacerbation within one month of surgery; both responded to high dose intravenous steroids. In one, new brain stem lesions were evident on MRI but not near the site of the electrode. No change in individuals' EDSS scores

\begin{tabular}{|c|c|c|c|c|c|}
\hline $\begin{array}{l}\text { Matsumoto } \\
\text { et al, } 2001{ }^{16}\end{array}$ & 3 & 3 months & 12 months & 0 & No exacerbations \\
\hline $\begin{array}{l}\text { Nandi et al, } \\
2002^{18}\end{array}$ & 1 & $\begin{array}{l}\text { Not specified; had } \\
\text { progressive worsening } \\
\text { of tremor in the } 6 \\
\text { months before surgery }\end{array}$ & 12 months & $?$ & $\begin{array}{l}\text { The patient experienced } \\
\text { progressive worsening of } \\
\text { walking, and left foot dystonia } \\
\text { developed between } \\
\text { approximately } 9 \text { and } 12 \\
\text { months post-surgery. It is } \\
\text { unclear whether this } \\
\text { represented a discrete relapse } \\
\text { or continuation of the } \\
\text { progression that was evident } \\
\text { before surgery }\end{array}$ \\
\hline
\end{tabular}

In general, the papers did not give specific criteria for exacerbation, but did provide clinical descriptions (summarised here).

EDSS, expanded disability status scale; MS, multiple sclerosis; MRI, magnetic resonance imaging; UTI, urinary tract infection. 
Table 3 Dartmouth-Hitchcock case series

\begin{tabular}{|c|c|c|c|c|c|c|c|}
\hline Patient & $\begin{array}{l}\text { Patient description } \\
\text { (age/sex/disease } \\
\text { duration*) }\end{array}$ & $\begin{array}{l}\text { Duration of } \\
\text { follow up }\end{array}$ & $\begin{array}{l}\text { Annualised } \\
\text { reprogramming } \\
\text { frequency }\end{array}$ & $\begin{array}{l}\text { Final DBS } \\
\text { settingst }\end{array}$ & Tremor rating $\ddagger$ & $\begin{array}{l}\text { Tremor } \\
\text { suppression: } \\
\text { description of } \\
\text { longitudinal } \\
\text { findings }\end{array}$ & Adverse effects \\
\hline 1 & $50 / M / 10$ & 20 months & 2.9 & $\begin{array}{l}\text { R stimulator: } \\
3.5 / 90 / 160 / B \\
\text { L stimulator: } \\
2.5 / 90 / 130 / M\end{array}$ & LUE: $3 / 1$; RUE: $3 / 1$ & $\begin{array}{l}\text { Initial cessation of LUE } \\
\text { tremor and significant } \\
\text { decrease in RUE tremor. } \\
\text { Effectiveness declined } \\
\text { over time, though } \\
\text { status is still } \\
\text { improved relative } \\
\text { to baseline with } \\
\text { optimal programming }\end{array}$ & $\begin{array}{l}\text { Transient } \\
\text { episode of RUE } \\
\text { weakness; } \\
\text { transient } \\
\text { episode of } \\
\text { diplopia; no MS } \\
\text { exacerbations }\end{array}$ \\
\hline 2 & $49 / F / 10$ & $\begin{array}{l}15 \text { months } \\
\text { for first } \\
\text { implant; } \\
3 \text { months } \\
\text { for second } \\
\text { implant }\end{array}$ & 5.6 & $\begin{array}{l}\text { R stimulator: } \\
\text { never turned } \\
\text { on; } L \text { stimulator: } \\
1.5 / 60 / 90 / B\end{array}$ & $\begin{array}{l}\text { LUE: } 3 / \text { na; RUE: } 3 / 0 \\
\text { ( } 3 / 1 \text { when stimulator } \\
\text { turned off) }\end{array}$ & $\begin{array}{l}\text { Improved, most notably } \\
\text { in the RUE; however, } \\
\text { left stimulator was } \\
\text { ultimately removed } \\
\text { (see text). Initial benefit } \\
\text { from surgery alone for } \\
\text { right stimulator, which } \\
\text { was never turned on. } \\
\text { Progression of LUE tremor } \\
\text { occurred over time; } \\
\text { final tremor rating was } \\
\text { unavailable as the } \\
\text { patient did not } \\
\text { return to clinic }\end{array}$ & $\begin{array}{l}\text { Transient pain } \\
\text { and swelling } \\
\text { around } \\
\text { insertion site } \\
\text { initially; } \\
\text { transient } \\
\text { paraesthesiae, } \\
\text { relieved by } \\
\text { temporarily } \\
\text { turning off the } \\
\text { stimulator; no } \\
\text { MS } \\
\text { exacerbations }\end{array}$ \\
\hline 3 & $37 / F / 2$ & $\begin{array}{l}31 \text { months } \\
\text { for } 1^{\text {st }} \\
\text { implant; } \\
30 \text { months } \\
\text { for } 2^{\text {nd }} \\
\text { implant }\end{array}$ & 3.1 & $\begin{array}{l}\text { R stimulator: } \\
4.8 / 120 / \\
\text { 145/M; } \\
\text { L stimulator: } \\
\text { 1.8/60/135/M }\end{array}$ & LUE: $3 / 1$; RUE: $3 / 1$ & $\begin{array}{l}\text { Improved; no significant } \\
\text { decline in benefit with } \\
\text { optimal programming }\end{array}$ & $\begin{array}{l}\text { Dysarthria§; } \\
\text { one } \\
\text { exacerbation } 4 \\
\text { weeks after } \\
\text { second implant }\end{array}$ \\
\hline 4 & $50 / F / 14$ & 21 months & 3.4 & $\begin{array}{l}\text { R stimulator: } \\
3.3 / 120 / \\
130 / \mathrm{B} ; \mathrm{L} \\
\text { stimulator: } \\
3.0 / 120 / \\
145 / \mathrm{B}\end{array}$ & LUE: $3 / 0$; RUE: $3 / 0$ & $\begin{array}{l}\text { Significant bilateral } \\
\text { improvement initially; } \\
\text { eventually had } \\
\text { return of bilateral } \\
\text { moderate to wide } \\
\text { amplitude tremor (LUE } \\
\text { worse than RUE), though } \\
\text { status is still improved } \\
\text { relative to baseline with } \\
\text { optimal programming }\end{array}$ & $\begin{array}{l}\text { No adverse } \\
\text { effects; no MS } \\
\text { exacerbations }\end{array}$ \\
\hline \multicolumn{8}{|c|}{$\begin{array}{l}\text { Postoperative magnetic resonance imaging revealed no evidence of intraoperative haemorrhage. One additional patient had an intraoperative seizure so } \\
\text { implantation was not completed at that time. Exacerbation was defined as the emergence of a new clinical symptom or reappearance of a previous symptom of } \\
\text { multiple sclerosis }{ }^{20} \\
\text { *Age (at time of surgery, years), sex (M, male; F, female), disease duration (years from diagnosis to surgery). } \\
\text { †Voltage/pulse width/frequency/monopolar (M) or bipolar (B). } \\
\text { fTremor rating (baseline/postoperative): } 0 \text {, absent; } 1 \text {, mild; } 2 \text {, moderate; } 3 \text {, severe. Postoperative ratings were made one month after surgery with stimulator } \\
\text { turned on, unless otherwise specified. } \\
\text { SReprogramming led to an acceptable balance between tremor control and dysarthria. } \\
\text { L, leff; LUE, left upper extremity; MS, multiple sclerosis; R, right; RUE, right upper extremity. }\end{array}$} \\
\hline
\end{tabular}

paraesthesiae, dizziness, and nausea 15 months after an otherwise beneficial implantation. Although it was not possible to detect the source of the problem, the unit was removed at the patient's request and her complaints resolved.

\section{DISCUSSION}

Deep brain stimulation offers a non-ablative alternative to thalamotomy for the surgical treatment of drug refractory tremor. Relatively few studies of outcome with this procedure have been reported in multiple sclerosis. The studies published to date involve a total of 75 completed implantations, and this report describes four additional cases. The compiled data suggest that chronic DBS often produces sustained improvement in tremor control in multiple sclerosis, as measured by tremor scales and self report instruments, for follow up periods of several months to a year. Nevertheless, these studies also show that complete cessation of tremor is not necessarily achieved, that there are cases in which tremor control decreases over time, and that frequent reprogramming appears to be necessary. Furthermore, the only direct comparison (to our knowledge) of DBS and ablative surgery in patients with multiple sclerosis showed no clear advantage of one method over the other, though the case sample was only a relatively small subset of a larger mixed sample in that study. ${ }^{15}$

Although patient selection criteria were not explicitly described in all studies, the more commonly used indications for surgery appeared to be severe or disabling tremor, failure to respond to medical treatment, absence of other severe sensory or motor problems that would continue to limit functioning even if tremor were alleviated, clinically stable disease for three to six months before surgery, and relatively preserved cognitive function.

Outcomes assessment-in terms of tremor measurement and effects on daily activities-could be improved in future studies of DBS in multiple sclerosis. Matsumoto and colleagues provide a review of considerations and options for measuring tremor suppression and the practical effects of DBS surgery in multiple sclerosis. ${ }^{16}$ They present a clinical tremor rating scale, a novel quantitative movement analysis technique, and a box-and-blocks test of prehensile function 
which appear promising. In that study, preoperative quantitative movement analysis data appeared to have value in predicting which patients would benefit most from surgery.

Whether effective tremor suppression translates to sustained improvement in daily living is somewhat difficult to assess and has received less empirical attention than tremor suppression on its own. In the studies from which relevant information could be gleaned, $76 \%$ of patients with multiple sclerosis showed benefit in terms of ability to grasp objects, self feed, print, write, or perform other everyday functions. $^{7811} 18$ These studies, however, accounted for only 25 of the 75 patients reported so far, and some studies showed no significant benefit in terms of everyday functioning (for example, Matsumoto ${ }^{16}$ ). Thus the practical impact of chronic DBS on everyday activities requires further examination, giving careful attention to selection of outcome measures appropriate to the range of potential benefit in the sample being studied. ${ }^{16}$ In some samples, regaining the ability to self feed, even at a rudimentary level, may translate to significantly improved quality of life and reduced patient care. In other samples, higher levels of independence in more complex daily functions may need to be measured as an outcome of treatment. One study reported a prevalent reduction in self reported fatigue as a function of decreased tremor during everyday activities, ${ }^{11}$ suggesting that it would be useful to include measures of fatigue in future trials. Given reported changes in cognitive and emotional status after DBS implantation in patients with Parkinson's disease, neuropsychological and psychiatric monitoring may also prove useful in multiple sclerosis.

The ventrointeromedial nucleus of the thalamus has been the most common surgical target for multiple sclerosis tremor, the ultimate placement being determined on the basis of, among other considerations, intraoperative tremor suppression relative to adverse effects ${ }^{17}$ and the somatotopic distribution of the intended target relative to the locus of the tremor. ${ }^{38}$ As noted, reprogramming is necessary to maintain effects over time, though whether that is related to underlying disease progression, declining effectiveness of the DBS, or both, is not clear. Some early decline in tremor suppression may be related to loss of microthalamotomy effects. ${ }^{17}$ Of note, one of the larger studies of DBS in multiple sclerosis reported no decline in response to optimally programmed stimulation during the follow up period; although stimulation levels had to be reprogrammed frequently, patients did not require progressively increased voltage, frequency, or pulse width of stimulation over time. ${ }^{3}$ Adverse effects are similar to those reported in other patient populations undergoing DBS implantation. ${ }^{19}$ Multiple sclerosis exacerbations have been reported after DBS implantation, but the available data do not clearly indicate whether they represent a change in exacerbation frequency relative to presurgical baseline.

\section{Conclusions}

Published reports indicate that chronic DBS is a relatively safe and effective means of reducing, but not eliminating, medically refractory tremor in multiple sclerosis. Safety considerations include risk of intracerebral haemorrhage. One limitation of most available studies is the relatively brief duration of follow up. Longer term outcome studies are needed. ${ }^{2}$ A second limitation relates to the nature of the outcomes assessments. Multidimensional assessment appropriate to the expected range of surgical benefit is most likely to be an accurate reflection of the effects of surgery. ${ }^{16}$ Therefore, prospective longitudinal studies using multidimensional outcome measurements are needed.

\section{ACKNOWLEDGEMENTS}

This work was supported in part by the National Multiple Sclerosis Society, the Hitchcock Foundation, and the Ira De Camp Foundation.

\section{Authors' affiliations}

H A Wishart, R M Roth, B C McDonald, L A Flashman, A J Saykin, Department of Psychiatry, Dartmouth Medical School, Lebanon, New Hampshire, USA

D W Roberts, C Hartley, Department of Surgery, Dartmouth Medical School

D J Coffey, C E Fadul, Department of Medicine, Dartmouth Medical School

A C Mamourian, Department of Radiology, Dartmouth Medical School

Competing interests: none declared

\section{REFERENCES}

1 Alusi SH, Worthington J, Glickman S, et al. A study of tremor in multiple sclerosis. Brain 2001;124:720-30.

2 Schulder M, Sernas T, Mahalick D, et al. Thalamic stimulation in patients with multiple sclerosis. Stereotact Funct Neurosurg 1999;72:196-201.

3 Montgomery EB, Baker KB, Kinkel RP, et al. Chronic thalamic stimulation for the tremor of multiple sclerosis. Neurology 1999;53:625-8.

4 Alusi SH, Aziz TZ, Glickman S, et al. Stereotactic lesional surgery for the treatment of tremor in multiple sclerosis: a prospective case-controlled study. Brain 2001; 124:1576-89.

5 Hooper J, Whittle IR. Long-term outcome after thalamotomy for movement disorders in multiple sclerosis. Lancet 1998;352:1984.

6 Shahzadi S, Tasker RR, Lozano A. Thalamotomy for essential and cerebellar tremor. Stereotact Funct Neurosurg 1995;65:11-17.

7 Brice J, McLellan L. Suppression of intention tremor by contingent deep-brain stimulation. Lancet 1980;ii:1221-22.

8 Nguyen JP, Degos JD. Thalamic stimulation and proximal tremor. Arch Neurol 1993;50:498-500.

9 Siegfried J, Lippitz B. Chronic electrical stimulation of the VL-VPL complex and of the pallidum in the treatment of movement disorders: personal experience since 1982. Stereotact Funct Neurosurg 1994;62:71-75.

10 Benabid AL, Pollak P, Gao D, et al. Chronic electrical stimulation of the ventralis intermedius nucleus of the thalamus as a treatment of movement disorders. J Neurosurg 1996;84:203-14.

11 Geny C, Nguyen JP, Pollin B, et al. Improvement of severe postural cerebellar tremor in multiple sclerosis by chronic thalamic stimulation. Move Disord 1996;11:489-94.

12 Whittle IR, Hooper J, Pentland B. Thalamic deep-brain stimulation for movement disorders due to multiple sclerosis. Lancet 1998;351:109-10.

13 Hay SR. Thalamic deep brain stimulation for treatment of visual symptoms in multiple sclerosis. Clinical eye and Vision Care 1999;11:121-131.

14 Taha JM, Janszen MA, Favre J. Thalamic deep brain stimulation for the treatment of head, voice, and bilateral limb tremor. I Neurosurg 1999;91:68-72.

15 Schuurman PR, Bosch DA, Bossuyt PM, et al. A comparison of continuous thalamic stimulation and thalamotomy for suppression of severe tremor. N Engl J Med 2000;342:461-8.

16 Matsumoto J, Morrow D, Kaufman K, et al. Surgical therapy for tremor in multiple sclerosis: an evaluation of outcome measures. Neurology 2001; 57:1876-82

17 Hooper J, Taylor R, Pentland B, et al. A prospective study of thalamic deep brain stimulation for the treatment of movement disorders in multiple sclerosis. Br J Neurosurg 2002; 16:102-9.

18 Nandi D, Chir M, Liu X, et al. Electrophysiological confirmation of the zona incerta as a target for surgical treatment of disabling involuntary arm movements in multiple sclerosis: use of local field potentials. J Clin Neurosci 2002;9:64-8.

19 Roth RM, Flashman LA, Saykin AJ, et al. Deep brain stimulation in neuropsychiatric disorders. Curr Psychiatry Rep 2001;3:366-72.

20 Lublin FD, Reingold SC. Defining the clinical course of multiple sclerosis: results of an international survey. Neurology 1996;46:907-11. 